\title{
FOURTH GENERATION OF CLOSED POPULATION HONEYBEE BREEDING \\ 2. Relationship between morphological and colony traits
}

\author{
Tibor 1. SZABO and Leonard P. LEFKOVITCH \\ Agriculture Canada Research Station, Box 29, Beaverlodge, Alberta, Canada \\ TOH OCO
}

Engineering and Statistical Research Centre, Agriculture Canada, Ottawa, Ontario, Canada KIA OC6

\begin{abstract}
SUMMARY
A study of the factors affecting honey production was conducted using the 4th generation of 10 queen families kept in isolated groups of 97 colonies in northern and 90 colonies in southern Alberta. Yearly selection was based on a short term colony gain at the beginning of honey flow. Nineteen morphological and 18 colony characteristics were compared. The two strains i.e. northern and southern, were different in 8 morphological and 14 colony traits. Honey production was significantly positively correlated with fall colony weight, worker brood area in May, viability of eggs, disease resistence or hygienic behaviour of bees, spring Nosema counts (negativc correlation), forewing area, hindwing area, femur, tibia and metatarsus length, third sternite length and wax mirror length $x$ wax mirror width. The largest canonical correlation of these factors with honey production, 1st harvest and 2nd harvest was 0.645 , which is significantly different from zero. These results suggest that morphological characters can be used to improve honeybee stock.
\end{abstract}

\section{INTRODUCTION}

Honey production is a complex characteristic of a honeybee colony, and so an understanding of the various factors affecting it is important in the successful management and selective breeding of honeybees. MiLNE (1980) summarized published research concerned with the correlation of honeybee size and honey production and found significant associations between the pupal weight of workers and the colony honey production. MiLne and Pries (1984)

This publication is in commemoration of the Centennial of the Experimental, Farm Stations Act in Agriculture Canada, 1886-1986, MS 86-19, Contribution $n^{\circ} I-878$, Engineering and Statistical Research Centre 
showed that honey production was correlated significantly with the length and area of the corbiculae. SzABo (1982) found significant correlations between honey production and other characteristics of the colony. A multiple correlation of honey production with short term weight gain, capped worker brood area and $24 \mathrm{~h}$ pollen collection, 0.902 to 0.994 was found. WoyKe (1984) summarized the literature on brood rearing cycle and the length of life of honeybees and the relationship between colony population and honey production. For temperate regions, he concluded that honey production is governed largely by the interaction of 3 factors : average daily brood production, length of worker life and individual productivity of workers. These studies demonstrate that honey production is related to a number of factors in a complex way. The purpose of the present investigation was to evaluate a large number of morphological and colony traits simultaneously for their effects on honey production.

\section{MATERIALS AND METHODS}

Honeybee stock, selection, strain of bees, queen rearing, isolated mating yards and management of the colonies are described by SzABo and LefKovitch (1987). From the 4th generation of selected northern strain of bees at Falher, either 9 or 10 colonies were chosen from each of 10 families (one colony was missing in each of three families). From the selected southern strain at Scandia, 10 colonies were chosen from each of 9 families. The total number of colonies used was 97 for Falher and 90 from Scandia. The two groups of bees originated from the same 10 queen families selected in 1979. The newly reared queens were mated in separate, geographically isolated yards, and then kept in two locations of northern and southern Alberta, approximately $700 \mathrm{~km}$ apart. It is the 4th generation of the two groups which is here compared in morphometrical and colony traits.

Colony traits: The traits of the colonies considered in the present study are listed below.

1. Weight of queen (mg) within $1 \mathrm{~h}$ of emergence ; analyzed as logarithms.

2. Start of oviposition in days.

3. Fall colony weight $(\mathrm{kg})$, including food and hive, in the middle of October.

4. Spring colony weight $(\mathrm{kg})$ including food and hive, measured in early April for indoor wintering and middle of May for outdoor wintering.

5. Fall Nosema spores : the average number of spores in millions per bee. The samples were taken in early September, 25 bees were collected at the hive entrance and assessed (CANTwELL, 1970).

6. Spring Nosema spores: the average number of spores in millions per bee. The samples were taken during end of March and early April.

7. Population : the total number of combs completely covered by bees in a colony during the middle of May.

8. Worker brood area (in $10 \mathrm{~cm}^{2}$ ) : the area of capped worker brood per colony, measured on both sides of each comb, using a plexiglass grid.

9. Drone brood area : the area of capped drone brood measured as for worker brood area.

10. Temper : number of stings received by a black suede leather ball while swinging for 60 seconds at the front of the hive entrance (see methods of SugDeN and Furgala, 1982).

11. Quietness : a score based on the area of comb remaining covered by the bees after 5 minutes on a comb holder outside the hive $(0=$ the comb completely covered by bees, and $10=$ all bees have left the comb). 
12. Brood viability : 100 minus mortality of eggs on a $10 \times 10$ worker cell area. One hundred minus the percentage of cells emptied (see methods of MAUL, 1972). The data were expressed as logits i.e. log [percent/(100-percent)].

13. Propolizing : amount of propolis deposited on frames and bottom board. Score : $1=$ practically none, 2 = usual amount, 3 = more than usual.

14. Fall population, measured the same way as in (7) except the measurements were taken at the end of October, prior to wintering.

15. Disease resistance : a colony's ability to uncap and remove $25 \mathrm{~cm}^{2}$ freeze killed brood within 24 hours and the percentage of cells emptied.

16. Honey production : net total weight of honey produced by a colony over the whole season ; analyzed as logarithms.

17. First harvest : weight of honey removed during the first pooling of honey supers from the colonies on July 22, 1983 ; analyzed as logarithms.

18. Second harvest : weight of honey removed on August 8,1983 ; analyzed as logarithms.

\section{Morphological characteristics}

Collecting young bees from the brood area was not considered because drifting was virtually eliminated by facing the hive entrances in various directions and by painting them in various colors. During the 1983 season, 20 bees were collected from the hive entrance of each colony and killed in a killing jar made with ethyl acetate or cyanide so as to ensure proboscis extension. Ten bees were frozen and later mounted for tergite colour analysis. The ten other additional bees were preserved in a solution of equal parts of $95 \%$ ethyl alcohol, glycerine and distilled water (WAFA et al., 1965) for dissection ; eighteen characters from the right part of each bee were measured. The various parts of the bees were removed and measured under a microscope or stereo-dissecting microscope fitted with a calibrated micrometer reticule in one eyepiece.

Nineteen morphological characteristics were measured $(\mathrm{mm})$ or calculated from each colony as listed below. All characteristics are described by RutTNER et al, (1978) unless stated otherwise.

1. Proboscis length.

2. Forewing length.

3. Forewing width.

4. Cubital vein a.

5. Cubital vein $b$.

6. Cubital index $a / b$.

7. Number of discodial cell hairs in $0.4 \mathrm{~mm}^{2}$ area (WOYKE, 1978a).

8. Hindwing length (Daly and Balling, 1978).

9. Hindwing width (Daly and Balling, 1978).

10. Number of hamuli (DALY and Balling, 1978).

11. Femur length.

12. Tibia length.

13. Metatarsus length.

14. Metatarsus width.

15. Third sternite length.

16. Wax mirror length.

17. Wax mirror width.

18. Distance between wax mirrors.

19. Tergite colour patterns : percentage of bees classified in colour classes from 6 to 10 (See colour classes: WoYke, 1978b).

\section{Statistical Analysis}

The means given in Tables 1, 2, 3 and 4 are in the original units, and were calculated either directly, or after back transformation, adjusting for bias, of the transformed values. The analyses, both univariate and multivariate, were performed in the transformed scales; all inferences are based on these. 
Analyses of variance of the original or transformed data were performed; simple and canonical correlations were computed after adjusting for strain and family. Analyses for the three variables representing honey production, with each of the remaining 34 variables as covariates, were used to determine which alone appear to account for a significant amount of any differences in strain and family. Morphological measurements were made on individual bees, but since these are essentially uniform genetically within a colony, they are not independent. Thus among the bees within colonies sums of squares are not repeated in Table 5, since they are deemed to be of no interest. Not surprisingly, analyses of colony means give virtually the same numerical values.

There were a number of missing values in the data ; departure from balance can be measured by the excess over $100 \%$ of the sum of the values in Table 5 for each variable. All analyses were performed using GENSTAT, release 4.04 .

TABL. 1. - Mean morphological measurements ( $\mathrm{mm}$ ) of the northern strain (no. 1) and 10 families of honeybees of the 4th generation of closed population breeding Strain 1 is the northern bees of Falher, with 10 families.

Strain 2 is the southern bees of Scandia, with 10 families.

Families 1 to 10 are the queen lines established in 1979.

$\mathrm{PL}=$ proboscis length $; \mathrm{FWL}=$ forewing lenght $; \mathrm{FWW}=$ forewing width $;$

$C V A=$ cubital vein $a ; C V B=$ cubital vein $b ; C I=$ cubital index $a / b$;

HRS $=$ number of discoidal cell hairs in a $0.4 \mathrm{~mm}^{2}$ area $; \mathrm{HWL}=$ hindwing length ;

$\mathrm{HWW}=$ hindwing width $; \mathrm{HA}=$ number of hamuli $; \mathrm{FE}=$ femur length $; \mathrm{TI}=$ tibia length $;$ $\mathrm{ML}=$ metatarsus length ; $\mathrm{MW}=$ metatarsus width ; $\mathrm{S3}=$ third sternite length ;

$\mathrm{WL}=$ wax mirror length $; \mathrm{WW}=$ wax mirror width $; \mathrm{WD}=$ distance between wax mirrors ; $\mathrm{TC}=$ tergite color $(\%) ; \mathrm{SED}=$ standard error of difference.

\begin{tabular}{c|c|c|c|c|c|c|c|c|c|c|c|c}
\hline \hline \multirow{2}{*}{$\begin{array}{c}\text { Obser- } \\
\text { vation }\end{array}$} & Strain & \multicolumn{10}{|c|}{ Family } \\
\cline { 2 - 11 } & 1 & 1 & 2 & 3 & 4 & 5 & 6 & 7 & 8 & 9 & 10 & SED \\
\hline PL & 6.52 & 6.45 & 6.48 & 6.47 & 6.53 & 6.51 & 6.56 & 6.58 & 6.57 & 6.52 & 6.57 & 0.034 \\
FWL & 9.30 & 9.33 & 9.26 & 9.30 & 9.30 & 9.36 & 9.30 & 9.32 & 9.25 & 9.30 & 9.26 & 0.041 \\
FWW & 3.19 & 3.19 & 3.18 & 3.21 & 3.21 & 3.20 & 3.18 & 3.23 & 3.18 & 3.17 & 3.15 & 0.017 \\
CVA & 0.56 & 0.58 & 0.57 & 0.56 & 0.57 & 0.56 & 0.58 & 0.55 & 0.56 & 0.58 & 0.54 & 0.010 \\
CVB & 0.24 & 0.25 & 0.23 & 0.28 & 0.25 & 0.24 & 0.23 & 0.25 & 0.25 & 0.24 & 0.24 & 0.006 \\
CI & 2.39 & 2.36 & 2.49 & 2.40 & 2.33 & 2.37 & 2.53 & 2.29 & 2.27 & 2.51 & 2.31 & 0.086 \\
HRS & 67.4 & 62.3 & 71.5 & 66.1 & 67.5 & 65.0 & 65.3 & 72.1 & 68.3 & 67.2 & 68.4 & 2.16 \\
HWL & 4.36 & 4.39 & 4.35 & 4.31 & 4.34 & 4.35 & 4.35 & 4.42 & 4.35 & 4.38 & 4.38 & 0.026 \\
HWW & 1.89 & 1.89 & 1.88 & 1.89 & 1.90 & 1.91 & 1.90 & 1.91 & 1.87 & 1.89 & 1.86 & 0.013 \\
HA & 21.3 & 20.9 & 21.4 & 21.2 & 20.8 & 22.1 & 22.0 & 20.4 & 21.3 & 21.3 & 21.2 & 0.382 \\
FE & 2.79 & 2.76 & 2.74 & 2.80 & 2.80 & 2.83 & 2.80 & 2.82 & 2.80 & 2.80 & 2.80 & 0.013 \\
TI & 3.18 & 3.20 & 3.12 & 3.18 & 3.18 & 3.11 & 3.21 & 3.24 & 3.21 & 3.18 & 3.20 & 0.033 \\
ML & 2.10 & 2.12 & 2.07 & 2.06 & 2.07 & 2.13 & 2.09 & 2.12 & 2.12 & 2.08 & 2.11 & 0.018 \\
MW & 1.24 & 1.24 & 1.23 & 1.22 & 1.25 & 1.26 & 1.23 & 1.24 & 1.26 & 1.23 & 1.24 & 0.010 \\
S3 & 2.89 & 2.89 & 2.88 & 2.87 & 2.92 & 2.92 & 2.89 & 2.89 & 2.89 & 2.89 & 2.89 & 0.020 \\
WL & 1.21 & 1.19 & 1.20 & 1.21 & 1.25 & 1.18 & 1.21 & 1.20 & 1.21 & 1.23 & 1.25 & 0.016 \\
WW & 2.23 & 2.22 & 2.20 & 2.24 & 2.25 & 2.22 & 2.23 & 2.25 & 2.22 & 2.27 & 2.24 & 0.017 \\
WD & 0.27 & 0.27 & 0.28 & 0.29 & 0.27 & 0.29 & 0.28 & 0.27 & 0.26 & 0.26 & 0.26 & 0.012 \\
TC & 35 & 34 & 23 & 44 & 43 & 49 & 33 & 32 & 43 & 18 & 37 & 12.4 \\
\hline
\end{tabular}




\section{RESULTS}

\section{Morphological and colony traits}

After 4 years of closed population breeding, the geographical groups were significantly different in 8 of the morphological characteristics. The southern bees were darker, their probosces and forewings longer (Tables 1, 2 and 5). Some of the families differed significantly from others in 15 of the characteristics. Only forewing length, tibia length, the distance between wax mirrors and tergite colour were similar in their mean values (Table 5) ; note, however, the significant interaction for the second and third of these.

As expected, the colony traits were even more different between the two geographical groups, 14 characteristics were significantly different. Most of these differences can be attributed to environmental differences (Tables 3, 4 and 5). Only in two colony characteristics of temper and queen weight were there significant family differences. The southern bees were significantly more

TABL. 2. - Mean morphological measurements ( $\mathrm{mm}$ ) of the southern strain (no. 2) with 10 families of honeybees of the 4th generation of closed population breeding See Table 1 for explanation of abbreviations

\begin{tabular}{c|c|c|c|c|c|c|c|c|c|c|c|c}
\hline \hline Obser- & Strain & \multicolumn{10}{|c}{ Family } \\
vation & 2 & 1 & 2 & 3 & 4 & 5 & 6 & 7 & 8 & 9 & 10 & SED \\
\hline PL & 6.56 & 6.61 & 6.61 & 6.54 & 6.57 & 6.56 & 6.57 & 6.62 & 6.51 & 6.52 & 6.54 & 0.034 \\
FWL & 9.28 & 9.34 & 9.34 & 9.24 & 9.28 & 9.31 & 9.27 & 9.26 & 9.26 & 9.27 & 9.27 & 0.041 \\
FWW & 3.16 & 3.17 & 3.18 & 3.13 & 3.17 & 3.16 & 3.14 & 3.15 & 3.15 & 3.14 & 3.15 & 0.017 \\
CVA & 0.59 & 0.58 & 0.59 & 0.57 & 0.59 & 0.59 & 0.60 & 0.61 & 0.60 & 0.59 & 0.56 & 0.010 \\
CVB & 0.24 & 0.23 & 0.23 & 0.24 & 0.24 & 0.24 & 0.24 & 0.24 & 0.24 & 0.23 & 0.23 & 0.006 \\
CI & 2.50 & 2.51 & 2.58 & 2.36 & 2.45 & 2.44 & 2.57 & 2.56 & 2.51 & 2.58 & 2.45 & 0.086 \\
HRS & 66.7 & 66.2 & 65.4 & 65.0 & 66.9 & 64.0 & 64.2 & 68.7 & 66.7 & 68.1 & 72.3 & 2.16 \\
HWL & 4.37 & 4.44 & 4.39 & 4.37 & 4.35 & 4.35 & 4.33 & 4.39 & 4.40 & 4.36 & 4.34 & 0.026 \\
HWW & 1.88 & 1.90 & 1.90 & 1.86 & 1.89 & 1.88 & 1.88 & 1.88 & 1.90 & 1.87 & 1.88 & 0.013 \\
HA & 21.2 & 21.3 & 21.2 & 20.9 & 20.8 & 22.0 & 21.8 & 21.3 & 20.9 & 20.8 & 21.4 & 0.382 \\
FE & 2.80 & 2.82 & 2.81 & 2.79 & 2.80 & 2.81 & 2.79 & 2.78 & 2.80 & 2.79 & 2.80 & 0.013 \\
TI & 3.19 & 3.21 & 3.21 & 3.19 & 3.19 & 3.19 & 3.19 & 3.18 & 3.19 & 3.17 & 3.17 & 0.033 \\
ML & 2.10 & 2.13 & 2.12 & 2.11 & 2.08 & 2.10 & 2.09 & 2.11 & 2.10 & 2.09 & 2.10 & 0.018 \\
MW & 1.22 & 1.24 & 1.23 & 1.24 & 1.23 & 1.22 & 1.22 & 1.22 & 1.22 & 1.21 & 1.22 & 0.010 \\
S3 & 2.89 & 2.90 & 2.88 & 2.87 & 2.92 & 2.91 & 2.87 & 2.89 & 2.89 & 2.90 & 2.88 & 0.020 \\
WL & 1.23 & 1.25 & 1.24 & 1.23 & 1.26 & 1.24 & 1.21 & 1.22 & 1.22 & 1.22 & 1.21 & 0.016 \\
WW & 2.22 & 2.22 & 2.18 & 2.22 & 2.24 & 2.23 & 2.21 & 2.22 & 2.22 & 2.19 & 2.24 & 0.017 \\
WD & 0.28 & 0.29 & 0.28 & 0.27 & 0.27 & 0.27 & 0.27 & 0.28 & 0.29 & 0.29 & 0.29 & 0.012 \\
TC & 56 & 59 & 63 & 54 & 63 & 57 & 38 & 55 & 51 & 62 & 56 & 12.4 \\
\hline \hline
\end{tabular}


TABL. 3. - Mean colony traits of the northern strain with 10 families of honeybees of the 4th generation of closed population breeding

See Table 1 for explanation of strain and family

QWT $=$ queen weight at emergence $(\mathrm{mg}) ; \mathrm{SO}=$ start of oviposition in days ;

FCWT $=$ fall colony weight $(\mathrm{kg}) ;$ SCWT $=$ spring colony weight $(\mathrm{kg})$;

FN = fall Nosema spores in million ; $\mathrm{SN}=$ spring Nosema spores in million ; POP population, no. of combs covered by bees in May ;

$\mathrm{WB}=$ capped worker brood area in $10 \mathrm{~cm}^{2} ; \mathrm{DB}=$ capped drone brood area in $10 \mathrm{~cm}^{2}$; TMP = temper, no. of stings $/$ ball ;

$\mathrm{QU}=$ quietness, score of 0 to 10 ; VIA $=$ brood viability, 100 minus $\%$ of egg mortality ;

PRO $=$ propolizing, score of 1 to $3 ;$ FPPOP $=$ fall population,

no. of combs covered by bees in October;

$\mathrm{DR}=$ disease resistance, \% of uncapped and removed dead brood ;

HONEY = total honey produced ; HARV1 = 1st harvest of honey;

HARV2 $=2$ nd harvest of honey.

\begin{tabular}{c|c|c|c|c|c|c|c|c|c|c|c|c}
\hline \hline \multirow{2}{*}{$\begin{array}{c}\text { Colony } \\
\text { trait }\end{array}$} & Strain & \multicolumn{10}{|c}{ Family } \\
\cline { 2 - 12 } & 1 & 1 & 2 & 3 & 4 & 5 & 6 & 7 & 8 & 9 & 10 & SED \\
\hline QWT & 220 & 218 & 223 & 217 & 210 & 226 & 218 & 213 & 228 & 227 & 218 & 6.5 \\
SO & 10 & 11 & 11 & 10 & 9 & 10 & 10 & 10 & 9 & 10 & 11 & 0,8 \\
FCWT & 62.5 & 62.3 & 62.7 & 62.5 & 64.7 & 57.3 & 63.9 & 65.4 & 59.6 & 62.7 & 64.5 & 2.5 \\
SCWT & 40.4 & 39.1 & 38.9 & 42.5 & 39.9 & 36.5 & 42.3 & 42.6 & 39.0 & 42.1 & 41.3 & 2.1 \\
FN & 3.24 & 2.95 & 2.30 & 1.83 & 2.28 & 0.0 & 8.95 & 5.95 & 0.44 & 3.90 & 3.90 & 2.64 \\
SN & 14.19 & 15.55 & 16.43 & 14.06 & 12.96 & 16.61 & 12.68 & 12.50 & 14.10 & 15.29 & 11.70 & 2.15 \\
POP & 11.9 & 11.9 & 12.4 & 12.5 & 12.7 & 9.0 & 12.6 & 13.4 & 10.4 & 11.2 & 12.4 & 1.53 \\
WB & 357 & 350 & 357 & 347 & 394 & 326 & 401 & 380 & 343 & 319 & 353 & 41.1 \\
DB & 13 & 12 & 14 & 15 & 16 & 6 & 21 & 18 & 7 & 15 & 9 & 7.4 \\
TMP & 0 & 0 & 0 & 0 & 0 & 0 & 0 & 1 & 0 & 0 & 0 & 1.5 \\
QU & 2 & 2 & 2 & 3 & 2 & 2 & 2 & 2 & 2 & 3 & 2 & 0.5 \\
VIA & 86 & 91 & 84 & 86 & 90 & 79 & 88 & 88 & 81 & 89 & 83 & 3.76 \\
PRO & 2 & 2 & 2 & 2 & 2 & 2 & 2 & 2 & 2 & 2 & 2 & 0.13 \\
FFPOP & 11.8 & 12.3 & 11.7 & 11.1 & 12.4 & 11.7 & 12.4 & 11.9 & 11.7 & 11.1 & 11.8 & 1.10 \\
DR & 46 & 66 & 51 & 33 & 44 & 55 & 40 & 52 & 42 & 44 & 37 & 14.2 \\
HONEY & 149.8 & 156.1 & 150.9 & 129.3 & 166.1 & 129.0 & 173.4 & 150.0 & 146.9 & 135.3 & 160.9 & 16.4 \\
HARV1 & 38 & 37 & 35 & 40 & 46 & 32 & 47 & 46 & 30 & 32 & 38 & 6.7 \\
HARV2 & 41 & 45 & 38 & 38 & 45 & 36 & 49 & 40 & 43 & 34 & 46 & 5.6 \\
\hline \hline
\end{tabular}

aggressive. The analyses of variance table (Table 5) shows the percentage of sum of squares attributable to each factor from Tables $1,2,3$ and 4 . A number of significant interactions were found between strains and families in some of the traits (Table 5).

\section{Honey production}

After accounting for the effect of Strain, Family, and their interaction, several of the morphological and colony traits significantly reduced the residual 
TABL. 4. - Mean colony traits of the southern strain with 10 families of honeybees of the 4th generation of closed population breeding

See Table 1 for explanation of strain and family and Table 3 for explanation of abbreviations

\begin{tabular}{c|c|c|c|c|c|c|c|c|c|c|c|c}
\hline \hline \multirow{2}{*}{$\begin{array}{c}\text { Colony } \\
\text { trait }\end{array}$} & Strain & \multicolumn{10}{|c|}{ Family } \\
\cline { 2 - 13 } & 2 & 1 & 2 & 3 & 4 & 5 & 6 & 7 & 8 & 9 & 10 & SED \\
\hline QWT & 225 & 230 & 215 & 217 & 216 & 225 & 235 & 239 & 228 & 228 & 220 & 6.5 \\
SO & 11 & 11 & 10 & 12 & 10 & 11 & 12 & 11 & 11 & 11 & 11 & 0.8 \\
FCWT & 56.6 & 53.6 & 54.3 & 54.2 & 58.6 & 57.0 & 56.5 & 57.1 & 58.9 & 57.8 & 57.7 & 2.5 \\
SCWT & 42.2 & 41.6 & 41.0 & 41.0 & 41.7 & 43.3 & 42.5 & 42.1 & 43.6 & 43.3 & 42.2 & 2.1 \\
FN & 1.14 & 1.15 & 1.00 & 2.60 & 0.21 & 0.0 & 0.15 & 0.05 & 1.80 & 3.75 & 0.65 & 2.64 \\
SN & 0.03 & 0.01 & 0.02 & 0.0 & 0.0 & 0.11 & 0.0 & 0.01 & 0.01 & 0.13 & 0.0 & 2.15 \\
POP & 6.6 & 6.2 & 7.5 & 5.2 & 7.5 & 5.9 & 6.9 & 7.1 & 6.5 & 7.9 & 5.8 & 1.53 \\
WB & 205 & 203 & 223 & 163 & 242 & 190 & 174 & 243 & 203 & 236 & 176 & 41.1 \\
DB & 17 & 10 & 26 & 14 & 19 & 21 & 24 & 16 & 7 & 17 & 14 & 7.4 \\
TMP & 2 & 2 & 1 & 5 & 2 & 7 & 0 & 2 & 0 & 1 & 0 & 1.5 \\
QU & 0 & 1 & 1 & 0 & 0 & 0 & 0 & 0 & 0 & 0 & 1 & 0.5 \\
VIA & 89 & 91 & 89 & 88 & 93 & 86 & 87 & 86 & 89 & 89 & 90 & 3.76 \\
PRO & 2 & 2 & 2 & 2 & 2 & 2 & 2 & 2 & 2 & 2 & 2 & 0.13 \\
FFPOP & 8.9 & 9.0 & 8.3 & 9.2 & 9.5 & 8.3 & 9.1 & 9.0 & 8.0 & 7.9 & 10.8 & 1.10 \\
DR & 57 & 61 & 55 & 61 & 55 & 50 & 45 & 80 & 58 & 51 & 55 & 14.2 \\
HONEY & 32.6 & 31.8 & 33.8 & 21.8 & 49.1 & 29.1 & 25.9 & 39.0 & 30.4 & 39.7 & 24.8 & 16.4 \\
HARV1 & 11 & 12 & 12 & 5 & 19 & 12 & 8 & 10 & 9 & 15 & 7 & 6.7 \\
HARV2 & 21 & 21 & 22 & 17 & 25 & 17 & 18 & 29 & 21 & 25 & 18 & 5.6 \\
\hline \hline
\end{tabular}

sum of squares. These included the forewing, hindwing, third sternite, colony weight and colony strength in May (Table 6). Other characters such as disease resistance and egg viability also significantly affected honey production (Table 6 ), but the weight of the queens on emergence (range 176-273 $\mathrm{mg}$, mean $223 \mathrm{mg}$ ) did not significantly reduce the unaccounted for variation in honey production.

Four groups of characteristics were formed from the significant individual covariates for further analysis of honey production, namely, estimates of forewing area (length $\times$ width), hindwing area (length $\times$ width), leg length (combined femur, tibia and metatarsus lengths) and wax mirror area (length $\times$ width). These were regarded as four covariates and used separately and together in further analyses of covariance; all (not surprisingly) were significant in accounting for the variability of honey production (Table 7), reducing the residual mean square more than any simple single covariate. 


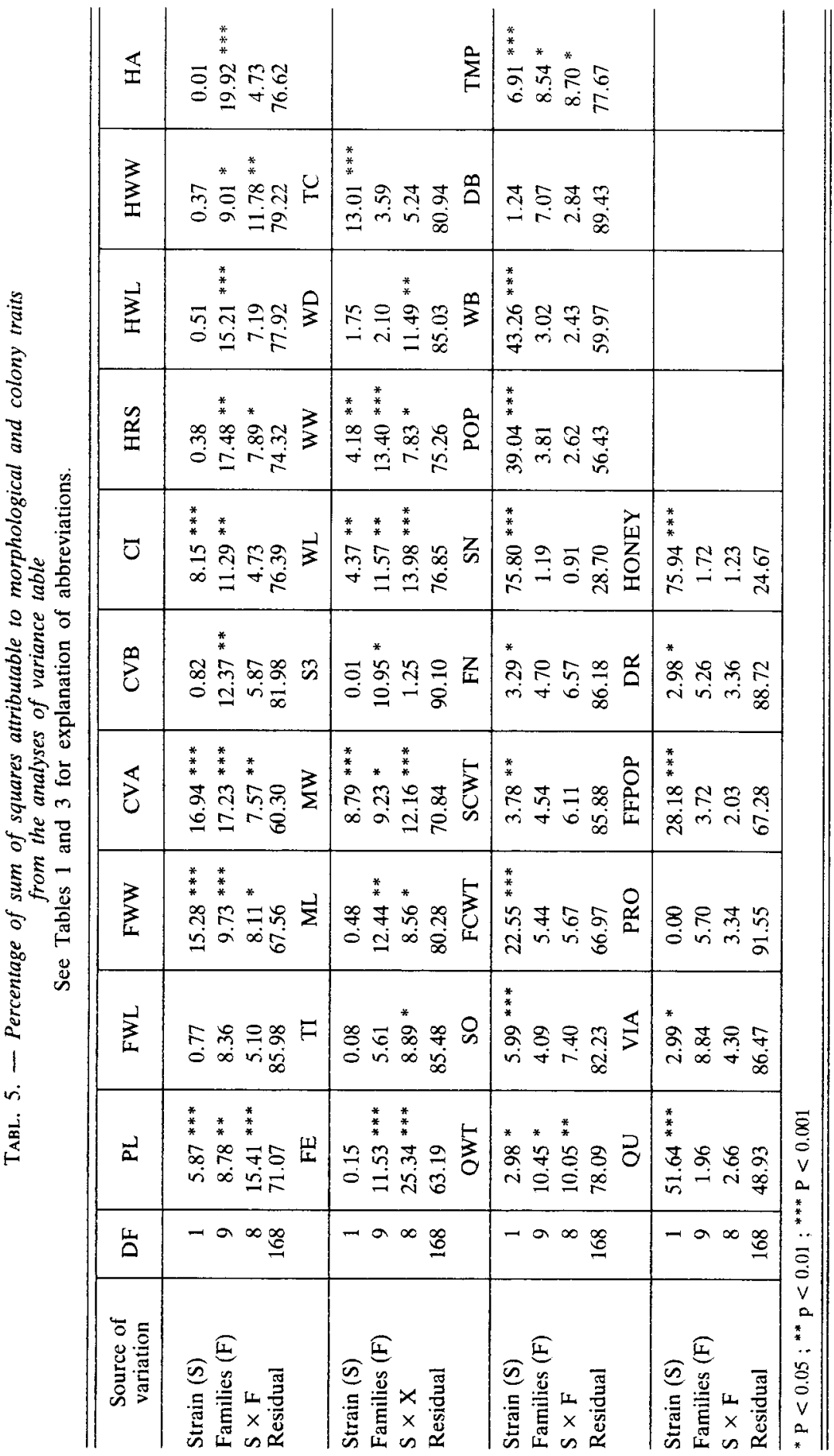


TABL. 6. - Significance of covariates in analyses of covariance of honey production, Ist harvest and 2nd harvest ; model otherwise as in Table 5.

See Tables 1 and 3 for explanation of abbreviations.

\begin{tabular}{|c|c|c|c|}
\hline Covariate & HONEY & HARV1 & HARV2 \\
\hline PL & ns & ns & ns \\
\hline FWL & $* *$ & $* *$ & $*$ \\
\hline FWW & $* *$ & * & $* *$ \\
\hline CVA & ns & ns & ns \\
\hline CVB & ns & ns & ns \\
\hline $\mathrm{CI}$ & ns & ns & ns \\
\hline HRS & ns & $*$ & ns \\
\hline HWL & $* *$ & $\mathrm{~ns}$ & $* *$ \\
\hline HWW & $* *$ & $* *$ & $* *$ \\
\hline $\mathrm{HA}$ & ns & ns & ns \\
\hline $\mathrm{FE}$ & $* *$ & $*$ & $* *$ \\
\hline TI & $* *$ & $* *$ & $*$ \\
\hline ML & $* *$ & $\mathrm{~ns}$ & * \\
\hline MW & ns & ns & ns \\
\hline S3 & $* *$ & $* *$ & $* *$ \\
\hline WL & * & ns & ns \\
\hline WW & $* *$ & ns & $*$ \\
\hline WD & ns & ns & ns \\
\hline $\mathrm{TC}$ & ns & ns & ns \\
\hline QWT & ns & ns & ns \\
\hline $\mathrm{SO}$ & ns & ns & ns \\
\hline FCWT & $*$ & * & * \\
\hline SCWT & ns & * & * \\
\hline FN & ns & ns & ns \\
\hline SN & ns & $*$ & * \\
\hline POP & $* *$ & $* *$ & ** \\
\hline WB & $* *$ & $* *$ & $* *$ \\
\hline DB & $* *$ & $* *$ & $*$ \\
\hline TMP & ns & ns & ns \\
\hline QU & $\mathrm{ns}$ & ns & ns \\
\hline VIA & ns & ** & ns \\
\hline PRO & ns & ns & ns \\
\hline FFPOP & ns & ns & ns \\
\hline DR & $* *$ & ns & $*$ \\
\hline
\end{tabular}

ns $\mathrm{P}>0.05,{ }^{*} \mathrm{P}<0.05,{ }^{* *} \mathrm{P}<0.01$

TABL. 7. - Significance of covariates in analyses of covariance of honey production, Ist harvest and 2nd harvest using 4 compound characteristics; model otherwise as in Table 5.

FRWNG $=$ FWL $\times$ FWW $;$ HWNG $=$ HWL $\times$ HWW $;$ LEG $=\mathrm{FE}+\mathrm{TI}+\mathrm{MT}$; WAX $=$ WL $\times$ WW. See Table 1 for explanation of abbreviations

\begin{tabular}{c|c|c|c}
\hline \hline Covariate & HONEY & HARV1 & HARV2 \\
\hline FRWNG & $* *$ & $* *$ & $* *$ \\
HWNG & $* *$ & $* *$ & $* *$ \\
LEG & $* *$ & $* *$ & $* *$ \\
WAX & $* *$ & ns & $*$ \\
\hline
\end{tabular}

ns $\mathrm{P}>0.05,{ }^{*} \mathrm{P}<0.05,{ }^{* *} \mathrm{P}<0.01$ 


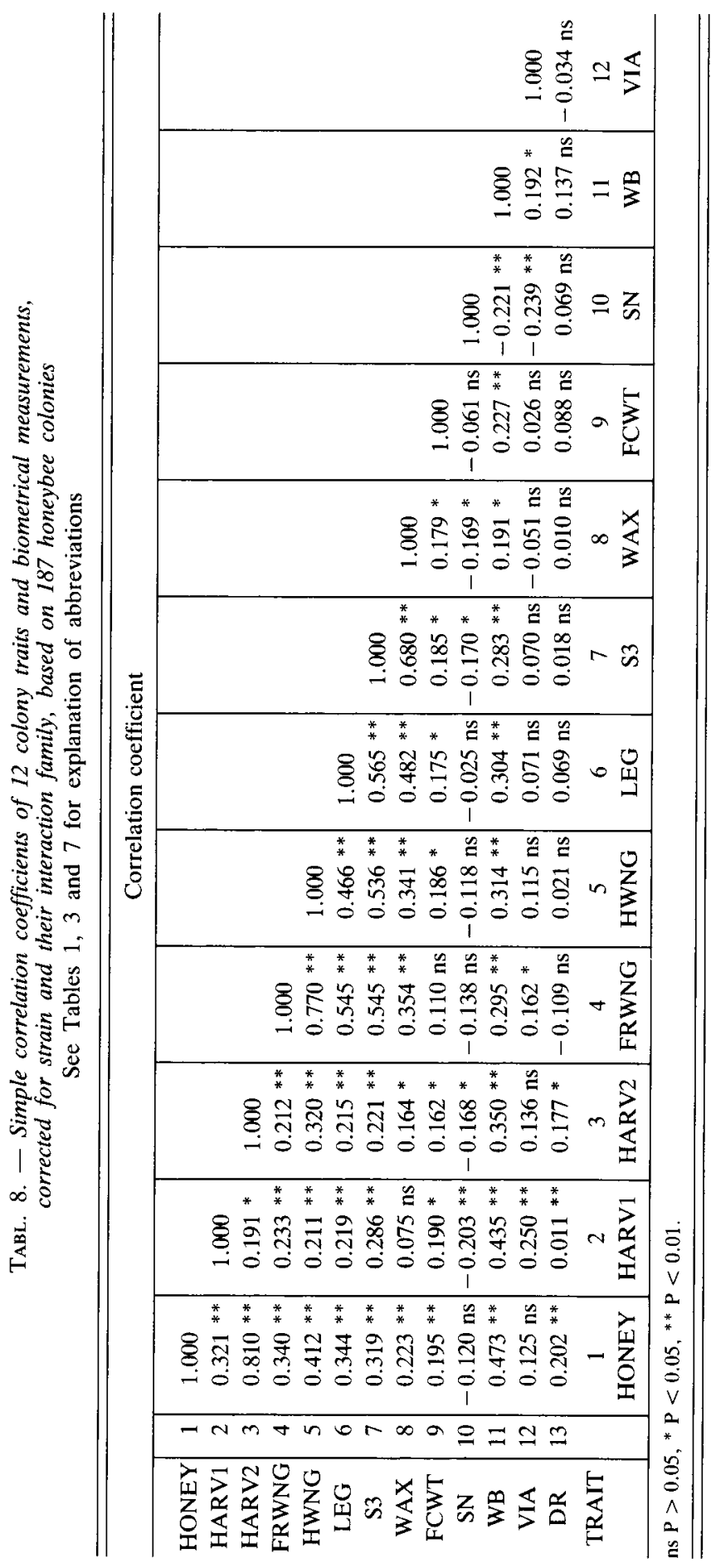




\section{Simple and canonical correlations}

The residuals from the four compound and six other important (simple) characteristics, after adjusting for strain and family, were obtained, and the correlations with the residuals from honey production total and those of the 1st and 2nd harvests were calculated (Table 8). Eight for the ten traits considered were significantly correlated with honey production. The two that were not, spring Nosema counts and brood viability, were significantly correlated with the 1st harvest yield. It seems that high spring Nosema counts are assuciated with reduced yield at the 1st and 2nd harvest, but that the total crop was not significantly affected.

The maximum canonical correlation between the set honey, 1st harvest, 2nd harvest $\}$ and the remaining ten in Table 8 was 0.6451 , significantly different from zero, i.e. there is good evidence of a relationship between the set of morphological attributes and the colony economy.

\section{DISCUSSION AND CONCLUSIONS}

Honey production is dependant on the colony's population and on the industry of its occupants (SzABo, 1982). WoyKe (1984) formulated an equation for this which is that population depends on oviposition rate, brood viability and adult bee longevity (= length of adult worker life), while the industry of the bees is an expression of the amount of honey produced per bee (SzABo, 1982). Szabo and LefKovitch (1987) demonstrated that during 4 generations of closed population breeding, and selecting on short term colony gain at the beginning of the honey flow, a number of colony characteristics significantly changed. Consequently, many of the factors affecting honey production appear to be heritable, and should allow a better representation of the equation for honey production.

In the present paper, ten characteristics were identified as being significantly correlated with honey production (Table 8). A number of explanations can account for these results. All the observed characteristics can influence directly or indirectly the colony population and/or industry of the bees ; honey production is the expression of all.

Since large wings and legs probably enable bees to have a greater carrying capacity to collect more nectar and pollen, the productivity of those colonies of bees having large wings and legs is therefore expected to be greater. Tables 5 and 6 show that forewing and hindwing areas and leg length are associated with increased honey yield. Since body size (RutTNER and MACKenSEN, 1952) and honeybee pupal weight (MILNE and FrIARS, 1984) are heritable characteris- 
tics of the honeybee, wing measurement probably can be used as a selection criterion for higher honey production.

If bees with longer femura, tibiae and metatarsi are able to collect more pollen than those with shorter legs, the increased amount and quality of pollen may result in more brood rearing and increased length of life of adults. Consequently, colony population and productivity will increase. The significant positive association of leg length with honey production (Table 8) is also consistent with MrLne and PrIEs' (1984) findings that honey production is significantly correlated with the length of the corbiculae (tibiae).

Not all morphological measurements were found to be related to honey production. Proboscis length, cubital cell measurements, number of discoidal cell hairs, number of hamuli, metatarsus width, distance between wax mirrors and tergite colour characteristics appeared not to play a role in explaining honey production. Thus after adjusting for strain, tergite colour, although often emphasized by some beekeepers, appears not to be related to honey production (Table 6).

Although fall colony weight was significantly correlated with honey production (Table 8), the fall population was not. This suggests that the next year's population depends more on the food stores than on fall population, i.e. with the long wintering period in Alberta, the fate of the colony is determined by the stored food quantity and quality. It appears likely that colonies with large winter stores restrict brood-rearing in early winter and probably produce more and healthier bees with a long life span. Thus the fall population has a low influence on the next year's crop.

The presence of Nosema disease, indicated by high spring Nosema spore counts, highly reduced honey yield during the 1st harvest, significantly but to a somewhat lesser extent during the 2 nd harvest, although it had little effect on the total honey production. This disease especially damages the early spring population and consequently delays colony development, but in a long nectar flow season, the affected colonies are able to develop and collect honey. Disease resistance, however, had the opposite effect. Colonies with high disease resistance collected more honey; however, disease resistance had little effect on the 1st harvest. A possible explanation is that a certain number of bees is necessary in a colony to express this behaviour.

Brood viability is significantly linearly related to the 1st honey harvest, but has little influence on the total honey production. Probably the loss of eggs during the early spring wastes valuable cluster space and results in reduced colony population and honey production. During late spring and early summer, when there is a greater brood nest, the queen and colony can compensate for the lower egg viability, so that the total honey crop is not significantly altered. 
Honey production appeared not to be linearly related to the weight of the queen at emergence after adjustment for strain and family (Table 6). The queens reared in the present experiment were an average $223 \mathrm{mg}$ (range 176 to $273 \mathrm{mg}$ ), similar in weight to those reared by egg grafting method (ÖrösI PAL, 1962) with a mean weight of $224 \mathrm{mg}$ (range 172 to $285 \mathrm{mg}$ ). Thus queens reared in optimum conditions performed well and their weight differences were not reflected in colony productivity.

Colony temper (agressiveness) adjusted for strain and family did not contribute to honey production (Table 6). This observation is consistent with that of SUDGEN and Furgala (1982) that there is no relationship between colony aggressiveness and productivity. The data of Table 1 show that our bees were larger in ten characteristics, the same in one and similar in three average values to European bees (DALY and BAlling, 1978). For example, the forewing length of our bees ranged from 9.34 to 9.25 , the European bees 9.12 and the Africanized bees $8.65 \mathrm{~mm}$. The number of bristles on the front wing of our bees were similar to $A$. m. ligustica from California or from Italy (Woyke, 1978b). The tongue length and cubital index were similar to those of A. m. ligustica (Rutrner and MACKENSEN, 1952), and so the honeybees used in the present study are similar to $A$. m. ligustica.

Received for publication in September 1987. Accepted for publication in April 1988.

\section{ACKNOWLEDGMENTS}

We thank Diane T. Heikel and Paul van Westendorp for technical assistance and Joe St. Laurent, FAlHer and Ed Willms, Scandia for the use of their honeybee colonies. This project (no. 78-0056) was partially supported by Farming for the Future Agricultural Research Council of Alberta.

\section{RÉSUMÉ \\ LA $4^{c}$ GÉNÉRATION D'UN ÉLEVAGE D'ABEILLES EN POPULATION FERMÉE \\ 2. RELATION ENTRE LES CARACTERISTIQUES MORPHOLOGIQUES ET LES CARACTÉRISTIQUES DE LA COLONIE}

\footnotetext{
Dix colonies d'abeilles de l'Alberta ont été choisies comme colonies souches pour former jusqu'à 40 colonies filles. La descendance de ces 10 familles a été placéc dans le nord et dans le sud de l'Alberta (régions éloignées d'environ $700 \mathrm{~km}$ ) et, en ces deux endroits, on a produit deux lignées d'abeilles. Une étude des facteurs qui influencent la production de miel a été menéc sur la $4^{e}$ génération (10 familles comprenant 97 colonies dans le nord et 10 familles de 90 colonies dans le sud de l'Alberta). Chaque année la sélection de la colonie a porté sur le rendement en miel le plus élevé à court terme au début de la micllée (Szabo, 1982). On a utilisé un programme d'élevage en population fermée et deux lieux
} 
géographiquement isolés et dépourvus auparavant d'abeilles (l'un dans le nord, l'autre dans le sud). Les nouvelles reines élevées à partir des colonies sélectionnées ont été accouplées avec des mâles provenant des mêmes colonies. La nouvelle génération de reines a été introduite en août, dans leur région respective, dans des colonies orphelinées.

On a comparé 19 caractéristiques morphologiques et 18 caractéristiques de la colonie. Les deux lignées d'abeilles différaient l'une de l'autre par 8 caractéristiques morphologiques : les abeilles du sud étaient plus foncées et leur proboscis et leur aile antérieure étaient plus longs (Tabl. 1, 2 et 5).

On a trouvé 14 caractéristiques de la colonie significativement différentes entre les deux groupes géographiques (Tabl. 3, 4 et 5). La plupart de ces différences peuvent être attribuées à des conditions de milieu différentes.

Certaines de ces caractéristiques semblent ne pas être en relation avec la production de miel : le poids des reines à l'émergence, le comportement de défense, la longueur du proboscis, la taille des cellules cubitales, le nombre de poils dans la cellule discoïdale, le nombre de crochets alaires, la largeur du métatarse, la distance entre les miroirs à cire et la couleur du tergite (Tabl. 6 et 7 ).

La production de miel ne présente pas de corrélation significative positive avec le poids de la colonie à l'automne, la surface de couvain d'ouvrières en mai, la viabilité des œufs, la résistance aux maladies ou le comportement hygiénique, le nombre de Nosema au printemps (corrélation négative), la surface de l'aile antérieure et celle de l'aile postérieure, la longueur du fémur, du tibia et du métatarse, la longueur de $3^{\text {e }}$ sternite, la longueur et la largeur du miroir à cire (Tabl. 8). La corrélation canonique la plus élevée de ces facteurs de production de miel ( $1^{\text {re }}$ et $2^{\mathrm{e}}$ récoltes) est de 0,645 , ce qui est significativement différent de zéro. Ces résultats laissent penser que les caractéristiques morphologiques peuvent être utilisées pour améliorer le cheptel apicole. Toutes les caractéristiques observées peuvent influencer, directement ou indirectement la taille des colonies et/ou l'activité des abeilles; la production de miel en est l'expression globale.

Les abeilles utilisées étaient semblables à la race. A. m. ligustica.

\section{ZUSAMMENFASSUNG}

\section{DIE VIERTE GENERATION EINER ZUCHT IN GESCHLOSSENER POPULATION BEI DER HONIGBIENE}

\section{BEZIEHUNG ZWISCHEN MORPHOLOGISCHEN UND VERHALTENS-EIGENSCHAFTEN}

Zehn Völker der Honigbiene aus der Region Alberta wurden als Stammkolonien von bis zu 40 Tochterkolonien ausgewählt. Nachkommen dieser 10 Familien wurden im Norden und im Süden von Alberta (ca. $700 \mathrm{~km}$ voneinander entfernt) aufgestellt und an diesen beiden Standorten zwei getrennte Linien von Honigbienen gezüchtet. In der 4. Generation wurden an 10 Familien mit insgesamt 97 Völkern im Norden und 10 Familien mit 90 Völkern im Süden von Alberta die Faktoren, die die Honigproduktion beeinflussen, untersucht. Die Selektion in den vorangegangenen Jahren erfolgte auf der Basis des höchsten kurzfristigen Honigertrages zu Beginn der Erntezeit (SZABo, 1982). Es wurde ein Zuchtprogramm für geschlossene Populationen verwendet. Die zwei geographisch isolierten Standorte waren vorher frei von Honigbienen. Die von den ausgewählten Völkern neu gezüchteten Königinnen wurden mit Drohnen aus demselben Volk besamt. Die neue Königinnengeneration wurde im August in weisellos gemachte Völker ihres Standorts eingeweiselt.

Es wurden 19 morphologische und 18 Koloniemerkmale verglichen. Die zwei Linien von Bienen wichen im 8 morphologischen Merkmalen voneinander ab (die südlichen Bienen waren dunkler und ihr Rüssel und ihre Vorderflügel länger (Tab. 1,2 und 5).

Von den Koloniemerkmalen waren in den beiden geographischen Gruppen 14 signifikant unterschliedlich (Tab. 3, 4 and 5). Die meisten der Differenzen konnten auf Umweltunterschiede zurückgeführt werden. 
Einige der Merkmale schienen nicht mit der Honigproduktion verbunden zu sein : das Schlupfgewicht der Königin, das Verteidigungsverhalten, die Rüssellänge, die Größe der Cubitalzellen, die Anzahl der Haare in der Disćoidalzelle, die Zahl der Häkchen, die Breite des Metatarsus, der Abstand zwischen den Wachsspiegeln und die Farbe der Tergite (Tab. 6 u. 7).

Die Honigproduktion war signifikant positiv korreliert mit : dem Gewicht des Volks im Herbst, der Größe des Arbeiterinnen-Brutnests im Mai, der Überlebensfähigkeit der Eier, der Resistenz gegen Krankheiten bzw. dem Hygieneverhalten der Bienen, der Nosemazahl im Frühjahr (negativ korreliert), der Fläche des Vorderflügels, der Fläche des Hinterflügels, der Länge von Femur, Tibia und Metatarsus, der Länge des 3. Sternits, der Länge und der Breite des Wachsspiegels (Tab. 8). Die höchste kanonische Korrelation dieser Faktoren mit der Honigproduktion (erste und zweite Ernte) war 0.645, was signifikant von Null verschieden ist. Diese Ergebnisse weisen darauf hin, daß morphologische Merkmale zur Überprüfung des Honigbienenbestands verwendet werden können. Alle untersuchten Merkmale können direkt oder indirekt die Koloniegröße und/oder den Fleiß der Bienen beeinflussen ; die Honigproduktion ist ein Ausdruck dessen.

Die in dieser Untersuchung verwendeten Bienen sahen der Rasse Apis mellifera ligustica ähnlich.

\section{RÉFÉRENCES}

Cantwell G.E., 1970. - Standard methods for counting nosema spores. Am. Bee J., 100 (6) : $222-223$.

Daly H.V., Balling S.S., 1978. - Identification of Africanized honeybees in the Western Hemisphere by discriminant analysis. J. Kansas ent. Soc., 51(4): 857-869.

Maul V., 1972. - Program for breeding with defined sex alleles pp. 63-66. From : Controlled mating and selection of the honey bee, ed. F. Ruttner, Bucharest : Apimondia.

Milne C.P. Jr., 1980. - Laboratory measurement of honey production in the honeybee. 3. Pupal weight of the worker. J. apic. Res., 19 (3) : 176-178.

Milne C.D. Jr. Friars G.W., 1984. - An estimate of heritability of honeybee pupal weight. J. Heredity, 75 : $509-510$.

Milne C.P. Jr., Pries K.J., 1984. - Honcybce corbicular size and honey production. J. apic. Res., 23 (1) : $11-14$.

Örösı Pal Z., 1962. - Mehek között. Mezögazdasagi kiado, Budapest.

Ruttner F. Mackensen O. (1952). - The genetics of the honeybee. Bee Wld., 33 (4) : 53-62.

Ruttner F. Tassencourt L. Louveaux J., 1978. - Biometrical - statistical analysis of the geographic variability of Apis mellifera L. Apidologie, 9 (4) : 363-381.

Sugden M.A., Furgala B., 1982. - Evaluation of six commercial honey bee (Apis mellifera L.) stocks used in Minnesota. Part 2 - Aggressiveness and swarming. Am. Bee J., 122 (5) : 185-188.

Szabo T.I., 1982. - Phenotypic correlations between colony traits in the honey bee. Am. Bee J., 122 (10) : 711-716.

Szabo T.I., Lefkovitch L.P., 1987. - Fourth generation of closed population honey bee breeding. 1. Comparis of selected and control strains. J. apic. Res. In press.

Wafa A.K., Rashad S.E., Mazeed M.M., 1965. - Biometrical studies on the Egyptian honeybee. $J$. apic Res., 4 (3) : 161-166.

WoYke J., 1978a. - Comparative biometrical investigation on diploid drones of the honeybee. II. The thorax. J. Apic. Res., 17 (4) : 195-205.

Woyke J., 1978b. - Biology of reproduction and genetics of the honeybee. Final Technical Report. Warsaw.

WOYKE J., 1984. - Correlations and interactions between population, length of worker life and honey production by honeybees in a temperate region. $J$. apic. Res., 23 (3) : 148-156. 